\title{
Does Prejudice Mediate the Effect of Ethnocentrism on Discrimination? An Empirical Study on Interethnic Relations
}

\author{
Marselius Sampe Tondok, Dwiko Kusuma Indramawan, and Ayuni \\ Faculty of Psychology \\ Universitas Surabaya
}

\begin{abstract}
The purpose of this study was to examine whether prejudice was the mediator between ethnocentrism and interethnic discrimination. A survey was conducted at a university in Surabaya which has a multicultured student population $(N=300)$ recruited using incidental sampling. Data were collected using discrimination, ethnocentrism, and prejudice questionnaires. The hypothesis was tested using regression analysis with simple mediation. Results showed that prejudice was the mediator between ethnocentrism and discrimination $(t=12.637 ; p<$ .01 ); meanwhile ethnocentrism was not a predictor of discrimination when prejudice was controlled $(t=1.444 ; p>.05)$. Results also provide a suggestion to ethnic group members to be more open and control their prejudice toward other ethnic groups in order to grow positive inter-ethnic relationships.
\end{abstract}

Keywords: discrimination, prejudice, ethnocentrism, interethnic relations

Tujuan studi ini adalah menguji apakah prasangka menjadi mediator yang menjelaskan hubungan antara etnosentrisme dan diskriminasi antaretnis. Metode survei dengan incidental sampling $(N=300)$ dilakukan pada populasi mahasiswa sebuah universitas di Surabaya dengan populasi mahasiswa yang multikultur. Pengumpulan data menggunakan angket diskriminasi, etnosentrisme, dan prasangka. Hipotesis penelitian diuji menggunakan analisis regresi dengan mediasi sederhana. Hasilnya menunjukan prasangka sebagai mediator antara etnosentrisme dan diskriminasi $(t=12.637 ; p<.01)$; adapun etnosentrisme bukan prediktor terhadap diskriminasi ketika prasangka dikontrol $(t=1.444 ; p>.05)$. Hasil studi juga menyarankan agar para anggota kelompok etnik lebih terbuka dan mampu mengendalikan prasangka terhadap kelompok etnik lain agar hubungan antar-etnis dapat tumbuh kembang ke arah positif.

Kata kunci: diskriminasi, prasangka, etnosentrisme, hubungan antar-etnis

Discrimination, prejudice and stereotypes are not new phenomena for people around the world. In Indonesia, many intolerant behaviors are derived from group diversity and differences (Liliweri, 2005). Group diversity includes differences in 'SARA' (suku, agama, ras, antargolongan in Indonesian, or tribe, religion, race, intergroup in English) and other group-based differences. Discrimination, prejudice, and stereotypes based on 'SARA' are negative, intolerant behaviors that are still common in Indonesia. Because of this intolerance, a group or members of a group are adversely impacted by the negative behaviors.

In Indonesia, there are about 300 ethnic groups [sic] (Liliweri, 2005). Consequently, there are poten-

Correspondence concerning this article should be addressed to Marselius Sampe Tondok, Faculty of Psychology Universitas Surabaya, Jalan Raya Rungkut Mejoyo (Kalirungkut), Surabaya 60293. E-mail: marseliustondok@gmail.com tial conflicts or interethnic hostilities. Based on the Indonesian Central Bureau of Statistics' or BPS's 2010 data, the number of native-born ethnic population has reached $233,895,869$ people or 98.8 percent. Due to superiority in population, native Indonesians might not be able to accept other ethnic groups because of language, belief, and custom differences.

In the May 1998 riots, people and university students gathered to protest the increasing price of basic commodities. The ethnic Chinese community was accused to play a role in rupiah depreciation despite no accurate data or evidence that ethnic Chinese with all their shops and businesses had caused the collapse of rupiah. Many native Indonesians perceived that ethnic Chinese were not natives; they were merely immigrants. Several blog sites, on the behalf of native Indonesians, attached stigma to, denigrated ethnic Chinese. The native Indonesian 
community considered that ethnic Chinese had taken control the economy and politics of Indonesia. Another blog site indicating a rejection toward the existence of ethnic Chinese posted an article about ethnic Chinese who wanted to control Indonesia in various aspects, ranging from religion to politics (Baskom, E., 2012).

Ethnic Chinese have spread across all clusters of Surabaya (the east, central, west, north and south of Surabaya). With the existence of ethnic Chinese in all areas, native and Chinese Indonesians should be able to coexist. Nevertheless, in reality, conflicts often occur between the two ethnic groups, including the students from each ethnic group. Based on our interview with two students, it was revealed that they experienced negative treatment from others because of their ethnic differences. SD (an initial name, a sixth semester student) claimed that he was discriminated and humiliated with the word 'Chinese' and was isolated because he is a Chinese Indonesian. TDS (an initial name, a last semester student) was treated negatively by parents of his ex-girlfriend because he is a native Indonesian. Moreover, he admitted that once he had been expelled from his exgirlfriend's house and that his ex-girlfriend's parents shouted at him.

Based on previous data and phenomena, native and Chinese Indonesians who live in Surabaya are often involved in conflicts. The sources of conflicts are varied, one of them is the teaching from the social environment, particularly parents or relatives, as well as personal and cultural experiences. The following Table 1 indicates previous studies on inter-ethnic relations, particularly on ethnocentrism and prejudice.

Based on the previous studies (see Table 1), it can be concluded that there are many ethnic groups and tribes in Indonesia; therefore, prejudices and stereotypes toward other ethnic groups are likely to occur. We would like to know how discrimination enters the public life. Theoretically, discrimination as behavior could not be separated from prejudice which is the attitude that shape behavior. Prejudice is a negative attitude toward the members of a particular group, prejudice is based solely on the membership of a group (Myers, 2013; Correll, Judd, Park, \& Wittenbrink, 2010). In other words, discrimination is the product of prejudice and discrimination is essentially the action of prejudice. Furthermore, in relation to intergroup relations, prejudice is an attitude that could not be separated from the beliefs of individuals or groups, including ethnocentrism.
As is known, Indonesia has and preserves the slogans of Pancasila (five principles of the Indonesian State Philosophy: Belief in the One and Only God, A just and civilized humanity, A unified Indonesia, Democracy, led by the wisdom of the representatives of the People, and Social justice for all Indonesians) and 'Bhinneka Tunggal Ika' which means 'unity in diversity'. However, have the slogans been put into practice? Based on several "bad" incidents in Indonesia related to 'SARA', Indonesians living in a multicultural society should have learnt the lesson and reduced their prejudice and discrimination that is due to differences in social identities.

Discrimination and prejudice also occur among university students. Based on our preliminary study, we found several factors that caused discrimination, namely: personal experiences, significant others, and emotional influences. The three factors were revealed during interviews with several native Indonesian students from a private university, a multicultural campus in Surabaya. One of the students, RS (an initial name, 19 years old) admitted that he was uncomfortable in making friends with Chinese Indonesians because he had negative experiences when doing group assignments with ethnic Chinese students. He was ignored, was not involved in a group discussion, and even was not assigned any task. Furthermore, RS said that his grandmother (a significant other) had a negative impression about ethnic Chinese and warned him to avoid dating with a Chinese Indonesian girl. As a result, RS felt uncomfortable and finally left his prospective girlfriend who is a Chinese Indonesian. Emotion also plays a role in developing prejudice as stated by another native Indonesian student, DDE (an initial name, 20 years old, female). Based on her experiences, she felt disappointed and was reluctant to make friends with people from ethnic Chinese because her past experiences resulted in negative feelings. Furthermore, our observation on students' interactions in one of the faculties of the aforementioned private university showed that most students tended to mix and be in a group with others from the same ethnic group; native Indonesian students gathered with native Indonesian students, and so did the ethnic Chinese students.

In May 2016, we used elicitation interviews with ten native Indonesian students from various faculties to investigate their prejudices and stereotypes. The results showed that prejudices and stereotypes have spread across the faculties and almost all of the ten informants prejudiced against ethnic Chinese. 
Table 1

Previous Research on Interethnic Relations (Ethnocentrism and Prejudice)

Researchers and

Year of

Title

Participants

Results

Publication

\begin{tabular}{ll}
\hline Yulvika, U.E., & Analisis Etnosentrisme antar-kelompok \\
Rivaie, W., \& & Siswa di Kelas XI IPS SMAN 1 Sungai \\
Rustiyarso (2014) & Ambawang (Analysis of Ethnocentrism \\
& Among Students of Grade 11- Social \\
& Science, SMAN 1 Sungai Ambawang)
\end{tabular}

Ulaan, K., Herani, I. \& Rahmawati, I.(2016)

$\begin{array}{ll}\text { Prasangka Mahasiswa Papua pada Etnis } & \text { Papuan students } \\ \text { Jawa di Kota Malang (Prejudice of Papuan } & \text { who lived in } \\ \text { Students Toward Javanese in Malang) } & \text { Malang }\end{array}$

Ali, R., Indrawati, E. S., \& Masykur, A. M. (2010).

\section{Hubungan antara Identitas Etnik dengan Prasangka Terhadap Etnik Tolaki pada Mahasiswa Muna di Universitas Haluoleo Kendari Sulawesi Tenggara (The Relationship Between Ethnic Identity and Prejudice Toward Tolaki Ethnic Group By Students From Muna Ethnic Group at Haluoleo University, Kendari Southeast Sulawesi)}

$\begin{array}{ll}\begin{array}{l}\text { 11th grade } \\ \text { students majoring }\end{array} & \begin{array}{l}\text { The students mixed with students } \\ \text { from the same ethnic group be- } \\ \text { in social science }\end{array} \\ \text { cause they had similar identity } \\ \text { at SMAN 1 } & \text { and considered that their ethnic } \\ \text { Ambawang } & \text { group was better than others. }\end{array}$

The participants who showed prejudice toward ethnic Javanese had a number of stereotypes as their source of prejudice.

Students from Muna ethnic group who studied at Haluoleo University
There was a positive correlation between ethnic identity and prejudice toward ethnic Tolaki students by Muna ethnic group at Haluoleo University.
Most informants said that people from ethnic Chinese were stingy, insolent, and pinchpenny.

Based on the above explanations, native Indonesian students had stereotypes and prejudices toward Chinese Indonesian students. Such prejudices and stereotypes could not be separated from their social identity in which native Indonesian students viewed Chinese Indonesian students as their out-group. Moreover, there was a judgmental bias since native Indonesian students assumed that their ethnic group was better than ethnic Chinese (ethnocentrism). Nevertheless, we have not yet understood the level of discrimination and the way discriminatory behaviors of native Indonesian students against Chinese Indonesian students were influenced by prejudice, as well as whether prejudice was related or not to ethnocentrism. Therefore, this study aimed to examine how ethnocentrism influenced discrimination with prejudice as a mediator.

\section{Discrimination}

\section{Definition of Discrimination}

There are many definitions of discrimination as indicated by social scientists. In general, however, discrimination refers to an unfair, a negative treatment against a group or members of a group based on their characteristics or attributes, such as race, ethnicity, religion, sex or other specific characteristics (Al-Ramiah, Hewstone, Dovidio, \& Penner, 2010; Myers, 2013; Stangor, 2016). Meanwhile, Correll et al. 2010 define discrimination as behavior directed toward the members of a category that impacts them and this behavior simply occurs because they are the members of that category.

There are several types of discrimination. Based on their form, there are two types of discrimination: (1) intentionally, direct, explicit discrimination; and (2) subtle, indirect, unconscious, automatic discrimination. Based on the perpetrators, there are individual discrimination and institutional discrimination (Myers, 2013). In practice, individual discrimination involves real and direct circumstances. For example, when a Chinese Indonesian elementary school student walked home from school, he was confronted by several children who were also in elementary school but they were native Indonesians: "Hey there, pig, pig, a pig is passing by" while throwing stones at him. Meanwhile, institutional discrimination is indirect discrimination through rules or regulations. For instance, a Muslim teacher working in a Christian school wanted to wear a hijab but she was banned 
by the school's rule: wearing hijab or being suspended from work. The manifestations of discriminatory behavior are verbal and non-verbal hostility, avoidance of contact, aggressive behavior, and denial of opportunity and access or equal treatment ( $\mathrm{Al}$ Ramiah et al., 2010).

In line with the above explanation concerning interethnic relations, it can be concluded that discrimination is a distinctively negative behavior against an ethnic group or its members merely because of their different characteristics, which can be done directly or indirectly, individually or institutionally.

\section{Dimensions of Discrimination}

Discrimination as "prejudice in acts" has seven dimensions, as stated by Liliweri (2005), namely: (1) motivation; (2) discriminatory behavior; (3) impacts of discrimination; (4) the relationship between motivation and discrimination; (5) the relationship between discriminatory behavior and discrimination contexts; (6) institutional contexts; and (7) broader community contexts. This study aimed to investigate the levels of discriminatory behaviors that occur among students in a private university holding the principle/value of multiculturalism. Therefore, we used only two dimensions of discrimination, which are motivation and discriminatory behavior. The use of two dimensions of discrimination in this study was in line with Al Ramiah et al. (2010)'s two manifestations of discrimination, which are overt or direct, and subtle, unconscious or automatic. The motivation behind discrimination is related to drives and expectations within a person that are invisible (covert) which then manifest into a real action (overt).

\section{Factors Influencing Discrimination}

Theoretically, social psychologists have proposed various causative factors of discriminatory behavior. Al Ramiah et al. (2010) presented four main theories that explain the causes of discrimination, which are the social identity theory, behavior from intergroup affect and stereotype theory, aversive racism theory; and system justification theory.

Social identity theory. This theory argues that group members are motivated to protect their selfesteem and achieve positive and distinct social identity. Motivation to obtain positive social identity can result in discrimination (Martiny, \& Rubin, 2016).
Behavior from Intergroup Affect and Stereotype Theory. Echebarria-Echabe (2013); Boysen (2017) used BIAS (Behavior from Intergroup Affect and Stereotypes) to explain how stereotypes and emotions shape a tendency to act against other groups. The theory suggests that a relative status and competi-tiveness of a group determine stereotypes toward out-groups. The stereotypes predict affect (emotions/ attitudes) toward out-groups, and then affect pre-dicts a tendency to display discriminatory behavior against out-groups.

Aversive racism theory. According to Dovidio and Gaertner (2010), negative evaluations toward racial or ethnic minorities were recognized from persistent avoidance of interactions with other racial and ethnic groups. In contrast to traditional and overt racism, which is characterized by intense hatred for and discrimination against racial or ethnic minorities, aversive racism is characterized by implicit or unconscious discriminatory behavior.

System justification theory. This theory explains that social identity that underlies the need for positive distinctiveness is a function of an individual's positive feelings for ego justification and group justification. Positive or negative social identity depends on an individual's perception toward the fairness of a system underlying in-group and outgroup relationships (Jost, 2017; Jost, Becker, Osborne, \& Badaan, 2017).

Based on the above theoretical reviews, it can be concluded that in relation to interethnic relations, discrimination occurs because of prejudice arising from individuals' motivation to increase or maintain the social identity of their in-group.

\section{Prejudice}

\section{Definition of Prejudice}

According to Allport (1954), prejudice is an antipathy which is the result of false or inflexible generalizations. Such generalizations are due to superficial feelings or experiences toward a particular person or group of people. Myers (2013) defines prejudice as a negative attitude toward a group or an individual based on certain characteristics. The attitude is shaped by a combination of feelings, a tendency to act, and beliefs. According to Liliweri (2005), prejudice is a negative view that involves emotion toward an indi-vidual or a group as a result of comparison with one's 
own group. Based on these definitions, it can be concluded that prejudice is a negative attitude, reflecting a subjective way of thinking and feeling inside a person as a result of overgeneralization toward other ethnic groups.

\section{Components of Prejudice}

According to Myers (2013), prejudice is an attitude. Similar to an attitude in general, prejudice is a combination of three components or ABCs of attitudes: affect (feelings), behavior tendencies (inclinations to act), and cognition (beliefs). People with prejudice dislike out-groups or those with different characteristics (affective aspect), which can be seen from their tendency to behave differently and unfairly against their out-groups (conative aspect) as a result of their negative beliefs about the characteristics of a particular group (cognitive aspect).

\section{Factors Influencing Prejudice}

Based on different studies by social scientists, we conclude that ethnic prejudice occurs due to various factors. These factors include:

Authoritarian personality. Individuals with authoritarian personality adjust rigidly when interacting with people from other ethnic groups. Such personality may be developed because parents do not express their love and use strict discipline to their child; and therefore, their child learns to control his/ her anxiety by showing a rigid attitude. Adorno, FrenkelBrunswik, Levinson, and Sanford (1950) argue that individuals with authoritarian personality are particularly vulnerable to have prejudice and stereotypes.

Past experiences (the role of social learning). Myers (2013) suggests that raising children in certain ways might reduce or increase prejudice. The role of parents, religious communities, and society are important to maintain or reduce prejudice. According to the social learning theory, children have negative attitudes toward a certain ethnic group because they have a role model. The role model provides a social representation of how individuals should act as "we" (in-group) and "they" (out-group). Children observe and learn to imitate the views expressed by the role model who could be their parents, friends, teachers and other significant others. Children are supported by their environment and rewarded by their parents and significant others because they imitate the role model's views.
Conformity. Conformity is a change in individuals' behavior or belief as a result of real or imagined group pressure. A classical research conducted by Pettigrew (1958) in 1950s among white South Africans showed a significant positive correlation between conformity to social norms and prejudice toward other groups.

Ethnocentrism. Ethnocentrism is individuals' tendency to evaluate other cultures using their own norms and values. It also includes suspicion toward people from other cultures, which usually to weaknesses, have punitive attitudes, and obey their ingroup authority.

Socialization. Many prejudices are inherited from parents. Mass media, including television, movies, and advertisement, also features stereotypical images that degrade other groups, such as ethnic minorities, women, gays and lesbians, and people with disabilities. Various studies have shown that socialization by social agents, particularly parents, has an impact on children's prejudice (Cabrera, Kuhns, Malin, \& Aldoney, 2016).

Group closeness (in-group versus out-group). Group closeness is a process in which groups draw sharp boundaries between their in-group and outgroup. Interethnic prejudice arises because of interethnic social distance. According to the social identity theory (Turner \& Tajfel, 1986), an individual has social identity because of his/her membership to a particular social group, this results in a separation between his/her social worlds; that is, in-group, which is called "us" and out-group, which is called "them". Closed groups tend to resist interactions with outgroups, particularly inter-marriage. A study by Marista (2014) showed that individuals having friends from different ethnic groups had low levels of intergroup prejudice.

Social inequalities. Unequal status breeds prejudice. The social dominance orientation theory (Kteily, Sidanius, \& Levin, 2011) suggests that a group is motivated to dominate other groups in order to improve or retain its social status.

Economic benefits. Social studies have confirmed that prejudice increases when a group is in a direct competition with other groups to gain economic resources. These studies are helpful in explaining why prejudice increases dramatically during stressful economic and social periods. The realistic group conflict theory suggests that prejudice arises when groups compete for scarce resources (Maddux, Galinsky, Cuddy, \& Polifroni, 2008). 
Conflict. According to the conflict theory, in order to maintain a distinctive social status, power, and ownership, dominant groups believe that there is no competition for resources between their groups and minority groups. With respect to intergroup relations, the social dominance theory (Kteily, Sidanius, \& Levin, 2011) explains that a group has a motivation to dominate other social groups. Individuals or groups who perceived themselves as powerful could even do extreme violence against other people or groups in order to protect their interests. Meanwhile, the members of minority groups may reciprocate the violence to improve their condition (Myers, 2013).

In line with the previous theoretical explanations, it can be concluded that ethnic prejudice occurs not only due to a single factor but interactions between personal and social factors. Personal factors consist of authoritarian personality, previous experiences, and ethnocentrism. Meanwhile, social factors include group closeness, conformity, group inequities, economic benefits, and intergroup conflicts.

\section{Ethnocentrism}

\section{Definition of Ethnocentrism}

Bizumic (2014) stated that the term ethnocentrism was firstly introduced by Ludwig Gumplowich and then popularized by William G. Sumner. In the beginning, ethnocentrism was merely a sociological construct that described a conflict between in-group and out-group. Sumner (1906) defines ethnocentrism as an idea that one's ethnic group, which is viewed as his/her in-group, is more superior than other ethnic groups, this sometimes results in an inferior judgement to those who are from other ethnic groups or out-groups (Pocovnicu \& Vasilache, 2012; Njoroge $\&$ Kirori, 2014). Meanwhile, ethnocentrism as a socio-psychological construct defined by Bizumic (2015) as a person's belief in the superiority of his/her own ethnic or cultural group's values and practices compared to those from other cultures.

Levinson (1950) states that ethnocentrism arises from broad and rigid differences that are made between in-group and out-group. This involves negative stereotypes and hostile attitudes toward out-group. In contrary, there are positive stereotypes about one's in-group, obedience, and hierarchical and authoritarian views on intergroup interactions, in which the in-group has the most dominant position whereas the out-group is at subordinate position.
Based on previous definitions, it can be concluded that ethnocentrism is a set of beliefs that one's traditions and behaviors (in-group) are better than those of other cultures (out-group) and that one's culture should be used as the standard to judge other cultures. Sumner (1906) suggests the three aspects of ethnocentrism: (1) some societies have several characteristics in social life that can be hypothesized as syndromes; (2) ethnocentric syndromes are functionally related to the order and existence of a group and intergroup competitions; (3) there is generalization that all groups have the syndromes.

\section{The Relationship Between Ethnocentrism and Discrimination with Prejudice as a Mediator}

In terms of intergroup relations in campus setting, ethnic-based discrimination is considered real, negative, and unfair behaviors performed by native Indonesian students against ethnic Chinese students and vice versa. As negative behaviors against a certain group or members of a group (Myers 2013), discriminatory behavior in campus are manifested in various behaviors, such as mocking, insulting, bullying, rejecting/avoiding being friends with the person, either in formal groups (e.g., a group discussion in class) or in informal groups (e.g., a peer-group at campus). The causal relationships among ethnocentrism, prejudice, and discrimination are shown in Figure 1.

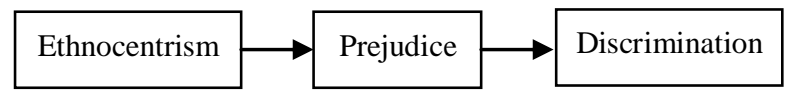

Figure 1. Causal relationships among the research variables.

Figure 1 reveals that discriminatory behavior occurs because of prejudice, which is defined as a negative attitude or dislike shown by native Indonesian students toward Chinese Indonesian students. Further, prejudice as the antecedent of discrimination is related to or is shaped by stereotypes, which is defined as false beliefs or inaccurate judgments that ethnic Chinese has a number of negative attributes, such as stingy, miserly, inflexible, and impolite. Stereotypes defined as beliefs or judgments that are believed to be true are developed from personal cognitive and social construction. In other words, social perceptions, feelings, and behaviors are shaped by 
social identification. Based on several previous studies, Van Veelen, Otten, Cadinu, \& Hansen (2016) concludes that those who strongly identifiy themselves with their in-group's beliefs (in-group think) are close and committed to their group, and act on behalf of their group.

As a personal cognitive construct, a number of negative stereotypes toward Chinese Indonesian students held by native Indonesian students are formed through direct experiences with ethnic Chinese. Meanwhile, stereotypes as social constructs are derived, shaped, and learned by native Indonesian students from their social environment, such as parents, friends, and mass media. Negative judgements and beliefs of native Indonesian students toward Chinese Indonesian students tend to be biased because their beliefs are based on ethnocentrism. According to Rubin and Badea (2010), individuals with high ethnocentrism tend to underestimate people from other groups (out-groups) in order to maintain their positive self-esteem (Iacoviello, Berent, Frederic, \& Pereira, (2017). Based on a social comparison with other ethnic groups, individuals tend to focus on the positive characteristics of their in-group and the negative characteristics of other ethnic groups (out-group). This phenomenon is known as an in-group bias in which the individuals tend to view their group in a positive way compared to other groups (Myers, 2013).

Ethnocentrism includes the subjective views or beliefs of native Indonesian students as the in-group. They tend to compare and provide negative judgements on the characteristics of Chinese Indonesian students as the out-group using the standards of their own ethnic group. Therefore, ethnocentrism is the basis or root of prejudice and discrimination, because the holders think that they are superior than others and perceive or prejudice against another ethnic group that they consider having cultural defects, which in turn arises different actions or treatment against a particular ethnic group (Liliweri, 2005).

Based on the above explanations, it can be concluded that prejudice plays a central role in the relationship between ethnocentrism and discrimination, particularly in interethnic relations between native Indonesian and Chinese Indonesian students. Prejudice, which is defined as negative feelings toward people from other groups, is shaped by ethnocentrism, which is defined as a tendency to have negative judgments toward other ethnic groups. Furthermore, prejudice possessed by native Indonesian students manifests in discriminatory behavior against ethnic Chinese students. Hence, the hypothesis of this study was as follows: there is a relationship between ethnocentrism and discrimination of native Indonesian students against Chinese Indonesian students with prejudice as the mediator.

\section{Methods}

\section{Research Variables}

Three variables in this study were: (1) discrimination as a dependent variable; (2) ethnocentrism as an independent variable; and (3) prejudice as a mediator variable.

\section{Operational Definition of Research Variables}

Discrimination is a negative and unfair behavior of native Indonesian students against Chinese Indonesian students as measured by the Discrimination Questionnaire. The questionnaire prepared by the authors consists of two dimensions, namely: motivation, and discriminatory behavior. The higher the participants' scores, the more frequent the native Indonesian students display discriminatory behavior against ethnic Chinese students. On the contrary, the lower the participants' scores, the less frequent the native Indonesian students display their discriminatory behavior against ethnic Chinese students.

Prejudice is a negative attitude or dislike shown by native Indonesian students toward ethnic Chinese students which is formed by the combination of feelings, tendencies to act, and beliefs. The Prejudice Questionnaire used in this study was based on the aspects of prejudice according to Myers (2013), consisting of cognitive, affective and conative aspects. The higher the participants' scores, the higher the native Indonesians' prejudice toward ethnic Chinese students. On the contrary, the lower the particiants' scores, the lower the native Indonesians' prejudice towards ethnic Chinese students.

Ethnocentrism is a view by native Indonesian students that their ethnic characteristics are better than those of ethnic Chinese students and this view is based on their own cultural standards. Ethnocentrism was measured using the Ethnocentrism Questionnaire. The questionnaire was based on the aspects of ethnocentrism according to Sumner (1906): (1) some societies have several characteristics in social life that can be hypothesized as syndromes; (2) ethnocentristic syndromes is functionally related to the order and existence of a group and intergroup com- 
petitions; (3) there is a generalization that all groups have the syndromes. The higher the participants' scores, the higher the native Indonesians' ethnocentrism. On the contrary, the lower the participants' scores, the lower the native Indonesians' ethnocentrism.

\section{Participants}

Participants in this study $(N=300)$ were native Indonesian students selected using accidental sampling from the population of students at a private university in Surabaya. In this university, the number of native and Chinese Indonesian students were about equal. The characteristics of participants were enrolled undergraduate students in all year level from the first to fourth year, whose both parents were native Indonesians. Participants consisted of $20.3 \%$ men and $79.7 \%$ women. The majority of participants $(96.3 \%)$ reported that they currently had friends or ever had friends from ethnic Chinese, while the rest of participants $(3.7 \%)$ did not have Chinese Indonesian friends. In terms of the relationships with ethnic Chinese, most participants (51.7\%) reported that in daily life, they had 'close', 'somewhat close' (33.3\%), 'somewhat not close' (10\%), and 'not close' relationships (4\%). Most participants (76.3\%) had neighbors from ethnic Chinese, while the rest of participants $(23.7 \%)$ reported that they had no neighbors from ethnic Chinese.

\section{Measures}

In this study, three measures in the form of questionnaires were used for collecting data to test the research hypothesis. The measures consist of the Questionnaire of Ethnocentrism, Prejudice, and Discrimination of native Indonesian students against ethnic Chinese students. The Discrimination Questionnaire was developed according to the blueprint in Table 2.

The Discrimination Questionnaire consists of 16 items in which six of them measure the aspects of motivation, and nine items measure the aspects of discriminatory behavior. Several examples of items are: (1) 'I do not want to help ethnic Chinese students who have learning difficulty'; (2) 'I do not want to be in a group with ethnic Chinese students for assignments', both items measure the aspect of motivation; (3) 'I will invite ethnic Chinese students to join my peer-group', this item measures the aspect of discriminatory behavior. The Discrimination
Questionnaire is a five-point Likert scale with response options ranging from strongly agree, agree, neither agree nor disagree, disagree, to strongly disagree. The Alpha Cronbach's reliability coefficient of this measure was .910 .

The Prejudice toward Ethnic Chinese Questionnaire was compiled based on the blueprint in Table 3.

The Prejudice Questionnaire consists of 24 items, in which 12 items measure the cognitive aspect, seven items measure the affective aspect, and five items measure the conative aspect. Several examples of items are: (1) 'I think ethnic Chinese holds a grudge against my ethnic group', the item measures the cognitive aspect; (2) 'I feel like I am being looked down when I am surrounded by Chinese Indonesians, this item measures the affective aspect; (3) 'I do not mind making friends with Chinese Indonesians', this item measures the conative aspect. The Alpha Cronbach's reliability coefficient for this measure was .883.

The Ethnocentrism Questionnaire is a five-point Likert scale with the response option ranging from strongly agree, agree, neither agree nor disagree, disagree, to strongly disagree. The questionnaire was developed using the blueprint in Table 4.

\section{Table 2}

Blueprint of the Discrimination Questionnaire

\begin{tabular}{lccr}
\hline Aspects & Favourable & Unfavourable & Total \\
\hline Motivation & $1,2,3,4$ & $12,13,14$ & 7 \\
Discriminatory & $5,6,7,8,9,10,1$ & 15,16 & 9 \\
behaviour & 1 & & \\
$\quad$ Total & 11 & 5 & 16 \\
\hline
\end{tabular}

Table 3

Blueprint of the Prejudice Questionnaire

\begin{tabular}{lccr}
\hline Aspects & Favourable & Unfavourable & Total \\
\hline Cognitive & $3,9,13,15,17,18,22$ & $2,6,14,16,21$ & 12 \\
Affective & $8,12,20,23$ & 7,11 & 6 \\
Conative & $1,10,19$ & $4,5,24$ & 6 \\
Total & 14 & 10 & 24 \\
\hline
\end{tabular}

Table 4

Blueprint of the Ethnocentrism Questionnaire

\begin{tabular}{lcr}
\hline Aspects & Item Number & Total \\
\hline Hypothesis as a syndrome & $1,8,13,14,17$ & 5 \\
Functional syndromes & $2,5,9,10,15,19$ & 6 \\
Generalization & 3,4, & 8 \\
& $6,7,11,12,16,18$ & \\
Total & & 19 \\
\hline
\end{tabular}


This questionnaire consists of 19 favorable items in which five of them measure the aspect of hypothesis as a syndrome, six items measure the aspects of functional syndromes, and eight items measure the aspects of generalization. Several examples of items are: (1) 'my culture should be the role model for other cultures', this item measures the aspect of hypothesis as a syndrome; (2) 'lifestyle in other cultures are as good as that in my culture', this item measures the functional syndrome aspect; (3) 'people from other cultures would be happier if they live like people from my culture', this item measures the generalization aspect. The questionnaire is a Likert scale with five options, which are strongly agree, agree, neither agree nor disagree, disagree, and strongly disagree, with a score ranging from 1 to 5 . The Alpha Cronbach's reliability coefficient of this questionnaire was .816. In sum, all of the three questionnaires used in this study were considered reliable because the Alpha Cronbach's coefficients were above 70 (Kaplan \& Saccuzzo, 2013).

Before the three questionnaires used for data collection, a validity test was conducted. Content validity is a process to ensure that an instrument measures the content area that is intended to measure (Urbina, 2014). A content validity test for the three questionnaires in this study was based on the the content validity ratio (CVR) with three raters. According to Lawshe (1975), the CVR score of each item ranges from 1 to -1 as measured by the following formula:

$$
C V R=\frac{n_{e}-(N / 2)}{N / 2}
$$

$$
\begin{array}{ll}
\text { Notes. } & \\
\mathrm{CVR} & =\text { Content Validity Ratio } \\
\mathrm{n} & =\text { The number of panel members indicating an item "essential" } \\
\mathrm{N} & =\text { The number of panel members }
\end{array}
$$

With three raters, an item is considered meeting the content validity criteria if the CVR score is 1 . If it is less than 1 , then the item should be revised according to the raters' feedback or deleted.

\section{Data Analysis}

The analysis used to test the hypothesis (i.e., examining the relationship between ethnocentrism and discrimination of native Indonesian students against ethnic Chinese students with prejudice as a mediator) was regression analysis with a simple mediation model, which is mediation analysis with one media- tor variable. The procedure to test mediation follows the mediation analysis procedure by Baron and Kenny (1986) as shown in Figure 2.

Statistical software to test this research hypothesis was SPSS (Statistical Package for Social Sciences) version 20.0 for Windows.

\section{Results}

\section{Description of Research Variables}

Research variables are described to provide an overview of the frequency distribution of participants' score category based on their total scores in the three research questionnaires. The score category was calculated based on ideal norming with five categories ranging from "very low", "low", "medium", "high", to "very high". The frequency distribution of participants' score category in the Discrimination Questionnaire is shown in Table 5.

Table 5 shows that most native Indonesian students who were the participants in this study had discrimination scores in the "low" category (179 people or $59.7 \%$ ) and "moderate" category (82 people or $27.3 \%$ ). Table 6 shows the frequency distribution of participants' score category in the Prejudice Questionnaire.

Table 6 shows that the majority of participants in this study had moderate levels of prejudice with 169 respondents $(56.3 \%$.). Table 7 shows the frequency distribution of participants' score category in the Ethnocentrism Questionnaire. Table 7 shows that ethnocentrism levels of most native Indonesian students who were the participants in this study were in the "moderate" category (181 people or $60.3 \%$.) and "high" category (102 people or $34.0 \%$ ).

\section{Hypothesis Testing}

The result of a statistical parametric test using regression analysis with a simple mediation model is summarized in Table 8.

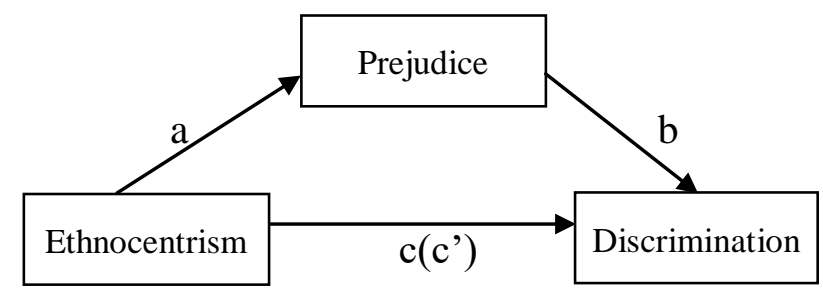

Figure 2. A model for data analysis. (adapted from Baron \& Kenny, 1986: 1176) 
The first-stage analysis using regression analysis was conducted to test the fulfillment of three required conditions (Baron \& Kenny, 1986) as shown in Figure 2. As described in Table 7, the first condition (path c) was met, showing that ethnocentrism was a significant predictor of discrimination $(t=10.596 ; p$ $<.01$ ). The second condition (path a) was also met, indicating that ethnocentrism was a significant predictor of prejudice $(t=12.064 ; p<.01)$. The third condition produced two estimated predictive values: the relation of prejudice to discrimination (path $b$ ), and the relation of ethnocentrism to discrimination (path c'). Prejudice was found to be a significant predictor for discrimination (path b), $t=12.637 ; p<.01$. However, ethnocentrism was not a significant predictor for discrimination when prejudice was controlled (line-c ') $t=1.455 ; p>.05$.

The result of mediation analysis using the PROCESS procedure (Hayes, 2013) was consistent with the result shown in Table 8. The contribution of ethnocentrism to prejudice was $38.2 \%\left(R^{2}=0.328\right)$. It was greater than the contribution of ethnocentrism to discrimination, which is $27.4 \%\left(R^{2}=0.274\right)$. The analysis examining the model revealed the significant role of both ethnocentrism and prejudice in predicting discrimination with $F(2,297)=165.87$ and $p$ $<.01\left(R^{2}=0.528\right)$.

\section{Discussion}

The result of this study showed that prejudice was the mediator variable in the relationship between ethnocentrism and discrimination. The result is in line with the theoretical concept proposed by Myers (2013). According to Myers, prejudice is the antecedent of discrimination and is shaped by stereotype as a cognitive dimension, which in this study is represented by ethnocentrism. With respect to interethnic relations, the connections among the three research variables in the perspective of social psychology can be explained using the basic concept that shapes the relationship of the three variables, namely social identity. According to the social identity theory (Martiny \& Rubin, 2016), individuals consider themselves in a certain category and associate themselves with a group (in-group), and then they compare their in-group with other groups (out-groups) with a tendency to assume that their group is more positive than other groups.

Furthermore, cognitive processes within individuals and groups that shape social identity as the
Table 5

Frequency Distribution of Discrimination Variable

\begin{tabular}{lccr}
\hline Category & Value Range & Frequency & Percentage \\
\hline Very high & $>49.00$ & 2 & 0.7 \\
High & $38.00-48.00$ & 19 & 6.3 \\
Medium & $27.00-37.00$ & 82 & 27.3 \\
Low & $16.00-26.00$ & 179 & 59.7 \\
Very low & $<15.00$ & 18 & 6.0 \\
Total & & 300 & 100 \\
\hline
\end{tabular}

Table 6

Frequency Distribution of Prejudice Variable

\begin{tabular}{lccr}
\hline Category & Value Range & Frequency & Percentage \\
\hline Very high & $>74.51$ & 1 & 0.3 \\
High & $59.00-74.50$ & 62 & 20.7 \\
Medium & $41.51-58.00$ & 169 & 56.3 \\
Low & $26.00-41.50$ & 61 & 20.3 \\
Very low & $<25.00$ & 7 & 2.3 \\
Total & & 300 & 100 \\
\hline
\end{tabular}

Table 7

Frequency Distribution of Ethnocentrism Variable

\begin{tabular}{lccr}
\hline Category & Value Range & Frequency & Percentage \\
\hline Very high & $>72.26$ & 1 & 0.3 \\
High & $54.51-72.25$ & 102 & 34.0 \\
Medium & $36.76-54.50$ & 181 & 60.3 \\
Low & $20.00-36.75$ & 14 & 4.7 \\
Very low & $<19.00$ & 2 & 0.7 \\
Total & & 300 & 100 \\
\hline
\end{tabular}

basis for ethnocentrism can be explained using the Integrative Model of Social Identification (IMSI) proposed by Van Veelen et al. (2016). According to the model, self-anchoring and self-stereotyping are two cognitive processes that are closely related to individuals and groups. Self-stereotyping occurs when individuals integrate the characteristics commonly found in their ethnic group into their self-concept. Meanwhile, self-anchoring, as opposed to self-stereotyping, indicates that individuals use their personal self as a positive standard to define their ethnic group (ingroup) and to distinguish them from other ethnic groups (outgroup, Van Veelen et al.).

The result of regression analysis with a simple mediation model (Baron \& Kenny, 1986) as seen in Table 8 indicated the $\mathrm{c}^{\prime}$ path with $t=1.455$ and $p>$ .05 . This was consistent with mediation analysis using the PROCESS procedure (Hayes, 2013), indicating that the contribution of ethnocentrism to prejudice $\left(38.2 \%\right.$ or $\left.R^{2}=0.328\right)$ was greater than the 
Table 8

Summary of the Results of Regression Analysis Based on Baron's and Kenny's Procedures

\begin{tabular}{lllccccr}
\hline \multirow{2}{*}{ Path } & \multicolumn{2}{c}{ Variable } & $\begin{array}{c}\text { Unstandardized } \\
\text { Coefficients }\end{array}$ & $\begin{array}{c}\text { Standardized } \\
\text { Coefficients }\end{array}$ & \multirow{2}{*}{$t$} & $p$ \\
\cline { 2 - 6 } & \multicolumn{1}{c}{ Independent } & Dependent & B & Std. Error & Beta & & \\
\hline c & Ethnocentrism & Discrimination & 0.422 & 0.040 & 0.523 & 10.596 & 0.000 \\
a & Ethnocentrism & Prejudice & 0.720 & 0.060 & 0.573 & 12.064 & 0.000 \\
b & Prejudice & Discrimination & 0.394 & 0.031 & 0.615 & 12.637 & 0.000 \\
c' & Ethnocentrism*Prejudice & Discrimination & 0.218 & 0.150 & 0.064 & 1.455 & 0.147 \\
\hline
\end{tabular}

contribution of ethnocentrism to discrimination (27.4\%; $R^{2}=0.274$ ). Based on both results, it can be concluded that the relationship between ethnocentrism and discrimination was completely mediated by prejudice. Therefore, the research hypothesis was accepted.

The result in Table 8 also showed that when the analysis was performed without considering the contribution of prejudice (path c), high levels of ethnocentrism of native Indonesian students significantly predicted high levels of discrimination against ethnic Chinese students. However, when the analysis was conducted by taking into account the role of prejudice (path c'), the result showed that the influence of ethnocentrism of native Indonesian students on discrimination against ethnic Chinese students was no longer significant. In other words, the positive influence of ethnocentrism of native Indonesian students on discrimination against ethnic Chinese students would be stronger or weaker depended on the higher or lower score of individuals' prejudice.

The result that confirmed the role of prejudice as the mediator in the relationship between ethnocentrism and discrimination is consistent with the theoretical concepts proposed by social psychologists. Myers (2013), for example, suggests inseparable relationships among belief, attitude, and behavior. Beliefs concerning the characteristics of a certain group (in this study, it is represented by ethnocentrism) will shape an individual's attitude toward out-group (in this study, it is represented by prejudice). Subsequently, attitude will affect individuals' behavior against other individuals or groups (in this study, it is discrimination against ethnic Chinese students). The result of this study is consistent with the result of the previous study by Ahmadi, Shahmohamadi, and Araghi (2011) showing that ethnocentrism generates prejudice, in addition to distrust, insecurity and discrimination against other ethnic groups. Individuals who have strong ethnic identity tend to have high levels of prejudice toward other ethnic groups (Ali, et al., 2010; Bergh, Akrami, Sidanius \& Sibley,
2016; Ulaan, Herani, \& Rahmawati, 2016).

Ethnocentrism as the belief in the superiority of one's own group (Sumner, 1906; Pocovnicu \& Vasilache, 2012) occurs because of in-group bias or in-group favoritism, as well as motivation of one's ethnic group to dominate other ethnic groups. Ingroup favoritism is an attributional error in which each individual or group tends to judge his/her own group more positively than other groups (Grimm, Utikal, \& Valmasoni, 2017; Huntera et al., 2017). Furthermore, using the social dominance theory (Kteily, Sidanius, \& Levin, 2011; Martiny, \& Rubin, 2016), ethnocentrism as the superiority over other ethnic groups occurs because each group unconsciously has a motivation to dominate other ethnic groups in order to obtain a higher social hierarchy.

Data shown in Table 6, reveal that native Indonesian students had scores of discrimination against ethnic Chinese students at the 'low' and 'moderate' categories. In addition, as seen in Table 7, the scores of prejudice towards ethnic Chinese students were in the 'medium' and 'low' categories. The low scores in both variables were not only because participants' ethnocentrism scores were low (Table 8), but also because most participants had an open interaction with ethnic Chinese in their daily life. Most participants reported that they currently had friends or ever had friends from ethnic Chinese $(96.3 \%)$, and the relationship was considered 'close' (51.7\%) and they generally had Chinese Indonesian neighbors (76.3\%). The fact that native Indonesian students in this study are accustomed to interacting with ethnic Chinese suggest that the quantity and intensity of contacts with other groups might decrease prejudice. This is consistent with previous studies indicating that prejudice would decrease with the increase of intense relationships with other groups, such as groups of people from other ethnicities and races (Marista, 2014), people with intellectual and developmental disabilities (Keith, Bennetto, \& Rogge, 2015), immigrants (Meeusen, 2014), and people with different 
sexual orientations (González-Jiménez, \& Fischer, 2017).

The result of this study also showed that ethnocentrism was the predictor of prejudice $(t=12.064$; $p<.01)$. This is in line with previous researches (Pocovnicu \& Vasilache, 2012; Buchori, 2017). Their studies showed that high ethnocentrism was associated with high prejudice toward other ethnicities. A classical research by Adorno et al. (1950) suggested that individuals with high ethnocentrism tended to prejudice against out-group and they were characterized by being intolerance, displaying punitive behaviors, and showing conformity to in-group authority, which were similar to the characteristics of authoritarian personality. People with authoritarian personality appear awkward in interacting with people from other ethnicities. The authoritarian personality might be developed from unloved and strict parenting style that resulted in children to learn to control their anxiety by being rigid.

Neuliep, Hintz, \& McCroskey (2005) conducted a correlational study of interethnic relationships in the organizational context with 117 fourth-year students at the Liberal Arts College in Midwestern, US. In this study, before completing a questionnaire, participants were shown a video of work interview with Korean students that were conducted at a financial aid office in a college in the US. The result showed that there was a negative association between ethnocentrism and prejudice that was represented by perceived interpersonal attractiveness, credibility, and recommended salary. The similar result was found when the participants were shown a video of interview with managers from other Asian backgrounds in a company in the US. The result showed that there was a negative relationship between ethnocentrism and perceived interpersonal attractiveness, credibility, attitudes toward managers, and work effectiveness. Previous studies have shown that ethnocentrism is an important factor in predicting individuals' behavior in interethnic relations. High ethnocentrism score is negatively correlated with the success rate of individuals working overseas (Reichard, Dollwet, \& Louw-Potgieter, 2014); In addition, ethnocentrism could decrease individuals' motivation to interact with people from other cultures (Yulvika et al., 2014) and increase superior feelings over other groups (Pettigrew \& Tropp, 2011). Other studies have shown that ethnocentrism could prohibit intercultural communication (Logana, Steelb, \& Hunta, 2016). Furthermore, individuals with high levels of ethnocentrism were often invol- ved in antisocial behavior against other ethnic groups (Pocovnicu \& Vasilache, 2012).

Multiple regression analysis used to test the model revealed the significant roles of both ethnocentrism and prejudice in predicting discrimination; $F$ $=165.87, p<.01$, and $R^{2}=0.528$. Ethnocentrism and prejudice of native Indonesian students were significantly predicted discrimination against ethnic Chinese students with effective contribution of $52.8 \%$. The remaining $(47.2 \%)$ was considered the influence of other variables apart from ethnocentrism and prejudice. Theoretically, the other factors that might influence discrimination are personality types, particularly authoritarian personality (Hodson, MacInnis, \& Busseri, 2017), past experiences through the learning process from social environment or through the socialization process by socialization agents, such as parents, friends, and mass media (Meeusen, 2014; Cabrera, Kuhns, Malin, \& Aldoney, 2016), the influence of attitudes on discriminatory behavior, significant others, and individuals' perceptions on difficulties or easiness in performing discriminatory behavior (Irwin, Symons, \& Kerr, 2009), inequality of social status (Kteily, Sidanius, \& Levin, 2011; Licciardello, Castiglione, Rampullo, \& Scolla, 2014), and the levels of competitions and intergroup conflicts for particular status and resources (Maddux et al., 2008).

\section{Limitations and Suggestions}

There are three limitations of this study that could be used for recommendations for further research. The limitations are related to the measurement of research variables, the theoretical concept used, and the results of study. First, in relation to the measurement of discrimination as a dependent variable, this study measured only two out of the seven dimensions of discrimination stated by Liliweri (2005), which are motivation and discriminatory behavior. The other dimensions of discrimination that are not measured in this study are the impact of discrimination, the relationship between motivation and discriminatory behavior, the relationship between discrimination and discrimination contexts, the institutional contexts and the broader community contexts. Future researchers could measure the seven dimensions of discrimination to obtain a more holistic concept of discrimination that could be used to explain discrimination at macro level (social policy praxis), not only at the micro level (individual) as measured in this study. 
Second, another limitation is on the theoretical concept used to construct prejudice. We consider prejudice as the construct of attitude. Therefore, we develop an interethnic prejudice measure based on the three aspects of attitudes, which are cognitive, affective, and conative. Alternatively, further studies could use other theoretical concepts of prejudice which emphasize the forms of intergroup prejudice, such as direct and indirect prejudice. One of the measures developed from such a theoretical concept is the subtle and blatant prejudice scale by Pettigrew $\&$ Meertens (1995). The blatant prejudice scale is a traditional measure of direct prejudice, whilst the subtle prejudice scale is a modern measure assessing indirect prejudice.

The third limitation is related to the results of this study. This study explains discrimination only from two research variables: prejudice and ethnocentrism, in the context of university students. Using the psychosocial perspective, i.e. social identity that shapes ethnocentrism and prejudice, the two variables explained $52.8 \%$ of the variance in discrimination. Nevertheless, theoretically, there are other factors that could influence discrimination, such as personaldemographic factors, as well as social and situational factors. Thus, further studies are suggested to include more antecedent variables to explain the underlying factors of discrimination and to investtigate these in different social settings.

\section{Conclusion and Recommendation}

Despite its limitations, the study has several practical contributions. The results revealed that university students who studied at a college with Chinese students had a lower level of prejudice towards Chinese ethnic groups than those who studied at a college without having Chinese students. This study triggers a cognitive exercise of the faculty of ethnic based universities to apply nonconventional policies in recruiting students. They should be aware of the value of multicultural activities which may increase harmony and reduce cultural isolation among students. Moreover, university should encourage students to engage with Chinese ethnic groups in learning, organization, and social activities.

Moreover, educators should encourage activities which involve students from diverse ethnic backgrounds to work together in non-competitive and engaging activities, such as goodwill trips and social services. Through these activities, a better understanding of other ethnic groups will be built. In ad- dition, these interactions will reduce the in-group and out-group feelings among the students. The activities will avoid any stereotypes, group exclusiveness, and ethnocentrism. Future research should explore the impact of students' backgrounds and religious orientations. By considering these variables, the influence of educational environments on prejudice can be clearly understood. Finally, prejudices to other groups, particularly against Chinese ethnic groups, will be reduced.

\section{References}

Adorno, T., Frenkel-Brunswik, E., Levinson, D., \& Sanford, R. N. (1950). The authoritarian personaliy New York: Harper.

Ahmadi, Y., Shahmohamadi, A., \& Araghi, M. M. (2011). The study of effect sociocultural factor on cultural intelligence. International Journal of $\mathrm{Hu}$ manities and Social Science, 1(12), 161-168.

Al-Ramiah, A., Hewstone, M., Dovidio, J. F., \& Penner, L. A. (2010). The social psychology of discrimination: Theory, measurement and consequences. In L. Bond, F. McGinnity \& H. Russell (Eds.). Making equality count: Irish and international research measuring equality and discrimination (pp. 84-112). Dublin: The Liffey Press

Ali, R., Indrawati, E. S., \& Masykur, A. M. (2010). Hubungan antara identitas etnik dengan prasangka terhadap etnik Tolaki pada mahasiswa muda di Universitas Halu Oleo Kendari Sulawesi Tenggara. Jurnal Psikologi Undip, 7(1), 18-26.

Allport, G. (1954). The nature of prejudice. Cambridge, MA: Addison-Wesley.

Bandura, A. (1986). Social foundations of thought and action: A social cognitive theory. Englewood Cliffs, NJ: Prentice Hall, Inc.

Baron, R. M., \& Kenny, D. A. (1986). The moderatormediator variable distinction in social psychological research: Conceptual, strategic and statistical considerations. Journal of Personality and Social Psychology, 51, 1173-1182.

Baskom, E. (2012). Masyarakat anti Cina seluruh Indonesia. Retrieved from http://masyarakatanti cinaseluruhindonesia.blogspot.com/?view=classic

Bergh, R., Akrami, N., Sidanius, J., \& Sibley, C. (2016). Is group membership necessary for understanding generalized prejudice? A reevaluation of why prejudices are interrelated. Journal of Personality and Social Psychology, 111(3), 367-395. https://doi.org/10.1037/pspi0000064 
Bizumic, B. (2014). Who coined the concept of ethnocentrism? A brief report. Journal of Social and Political Psychology, 2(1), 3-10. https://doi.org/ 10.5964/jspp.v2i1.264.

Bizumic, B. (2015). Ethnocentrism. In R. A. Segal \& K. von Stuckrad (Eds.), Vocabulary for the study of religion (Vol. 1, pp. 533-539). Leiden, the Netherlands: Brill Academic Publishers.

Bizumic, B. (2014). Who coined the concept of ethnocentrism? A brief report. Journal of Social and Political Psychology, 2(1), 3-10. https://doi.org/ 10.5964/jspp.v2i1.264.

Black, J. S. (1990). The relationship of personal characteristics with the adjustment of Japanese expatriate managers. Management International Review, 30(2), 119-134.

Boysen, G. A. (2017). Exploring the relation between masculinity and mental illness stigma using the stereotype content model and BIAS map. The Journal of Social Psychology, 157(1), 98-113. https://doi.org/10.1080/00224545.2016.1181600

Bukhori, B. (2017). Educational environment, ethnocentrism, and prejudice towards Indonesian Chinese. Anima Indonesian Psychological Journal, 32(2), 109-115. https://doi.org/10.24123/aipj.v32 i2.589

Cabrera, N., Kuhns, C., Malin, J. L., \& Aldoney, D. (2016). Helping children navigate a diverse world: Parents' contributions. Advances in Child Development and Behavior, 51, 81-102. https://doi. org/10.1016/bs.acdb.2016.05.002

Castelli, L., Carraro, L., Tomelleri, S., \& Amari, A. (2007). White children's alignment to the perceived racial attitudes of the parents: Closer to the mother than father. British Journal of Developmental Psychology, 25(3), 353-357.

Correll, J., Judd, C.M., Park, B. and Wittenbrink, B. (2010). Measuring prejudice, stereotypes and discrimination. In J. F. Dovidio, M. Hewstone, P. Glick and V. M. Esses (Eds.), The sage handbook of prejudice, stereotyping, and discrimination (pp. 45-62). Thousand Oaks, CA: Sage.

Dovidio, J. F., \& Gaertner, S. L. (2010). Aversive racism. In J. M. Levine \& M. A. Hogg (Eds.), Encyclopedia of group processes and intergroup relations (Vol. 1, pp. 48-51). Thousand Oaks, CA: Sage.

Echebarria-Echabe, A. (2013). Testing the BIAS map model: The positive effects of perceiving weakness and harmony in powerful out-groups. The Journal of Social Psychology, 153(6), 720-735. https://doi.org/10.1080/00224545.2013.826618
González-Jiménez, A. J., \& Fischer, V. (2017). Gender and sexual orientation among adolescents in Brazil: An analysis of the prejudice and bullying in the Educational Context. Procedia - Social and Behavioral Sciences, 237, 38-43. https://doi. org/10.1016/j.sbspro.2017.02.008

Grimm, V., Utikal, V., \& Valmasoni, L. (2017). Ingroup favoritism and discrimination among multiple out-group. Journal of Economic Behavior \& Organization, 143, 254-271. https://doi.org/10.10 16/j.jebo.2017.08.015

Hayes, A. F. (2013). Introduction to mediation, moderation, and conditional process analysis: A regression-based approach (1st ed.). New York: Guilford Press.

Hodson, G., MacInnis, C. C., \& Busseri, M. A., (2017). Bowing and kicking: Rediscovering the fundamental link between generalized authoritarianism and generalized prejudice. Personality Individual Differences, 104, 243-351. https://doi. org/10.1016/j.paid.2016.08.018

Huntera, J. A., Platowb, M. J., Moradia, S., Banksa, M., Hayhursta, J., Kafkaa, S., Iversena, G., Scobiea, O., Scarfa, D., Stringerc, M., O'Briend, K. S., \& Ruffmana, T. (2017). Subjective belonging and ingroup favoritism. Journal of Experimental Social Psychology, 73, 136-146. https://doi.org/10.1016/ j.jesp.2017.06.010

Iacoviello, V., Berent, J., Frederic, N.S., \& Pereira, A., (2017). The impact of in-group favoritism on self-esteem: A normative perspective. Journal of Experimental Social Psychology, 71, 31-41. https:// doi.org/10.1016/j.jesp.2016.12.013

Irwin, C., Symons, C. W., \& Kerr, D. L. (2009). Behavioral intention and behavior toward the obese on a college campus: An exploratory analysis of discriminatory behavior. Americal Journal of Health Education, 40(2), 106-117. https://doi.org/ 10.1080/19325037.2009.10599085

Jost, J. T. (2017). A theory of system justification. Psychological Science Agenda (PSA). Washington, DC: American Psychological Association.

Jost, J. T., Becker, J., Osborne, D., \& Badaan, V. (2017). Missing in (collective) action: Ideology, system justification, and the motivational antecedents of protest behavior. Current Directions in Psychological Science, 26, 99-108. https://doi. org/10.1177/0963721417690633

Kaplan, R. M., \& Saccuzzo, D. P. (2013). Psychological testing: Principles, applications, and issues. 8th ed. Boston, MA: Cengage Learning.

Keith, J. M., Bennetto, L., \& Rogge, R. D. (2015). 
The relationship between contact and attitudes: Reducing prejudice toward individuals with intellectual and developmental disabilities. Research in Developmental Disabilities, 47, 14-26. https:// doi.org/10.1016/j.ridd.2015.07.032.

Kteily, N. S., Sidanius, J., \& Levin, S. (2011). Social dominance orientation: Cause or 'mere effect'?: Evidence for SDO as a causal predictor of prejudice and discrimination against ethnic and racial outgroups. Journal of Experimental Social Psychology, 47(1), 208-214. https://doi.org/10. 1016/j.jesp.2010.09.009

Lawshe, C. H. (1975). A quantitative approach to content validity. Personnel psychology, 28, 563-575.

Levinson, D. J. (1950). Politico-economic ideology and group memberships in relation to ethnocentrism. In T. W. Adorno, E. Frenkel-Brunswik, D. J. Levinson, \& R. N. Sanford (Eds.), The authoritarian personality (pp. 151-221). New York: Harper \& Brothers.

Liliweri, A. (2005). Prasangka \& konflik, komunikasi lintas budaya masyarakat multikultur. Yogyakarta: Pelangi Aksara.

Licciardello, O., Castiglione, C., Rampullo, A., \& Scolla, V. (2014). Social Dominance Orientation, Cross-group Friendship and Prejudice towards Homosexuals. Procedia - Social and Behavioral Sciences, 116, 4988-4992. https://doi.org/10.10 16/j.sbspro.2014.01.1060.

Logana, S., Steelb, Z., \& Hunta, C. (2016). Intercultural willingness to communicate within health services: Investigating anxiety, uncertainty, ethnocentrism and help seeking behaviour. International Journal of Intercultural Relations, 54, 77-86. https://doi.org/10.1016/j.ijintrel.2016.07.007

Maddux, W. W., Galinsky, A. D., Cuddy, A. J. C., \& Polifroni, M. (2008). When being a model minority is good ... and bad: Realistic threat explains negativity towards Asian Americans. Personality and Social Psychology Bulletin, 34(1), 74-89.

Marista, Y. (2014). Perbedaan prasangka siswa Jawa terhadap Etnis Cina antara siswa SMA Negeri 2 Ungaran dengan siswa SMA Don Bosko Semarang. Empati, 3(2), 1-11.

Martiny, S. E., \& Rubin, M. (2016). Towards a clearer understanding of social identity theory's self-esteem hypothesis. In S. McKeown, R. Haji, $\&$ N. Ferguson (Eds.), Understanding peace and conflict through social identity theory: Contemporary global perspectives (pp. 19-32). New York: Springer. https://doi.org/10.1007/978-3319 -29869-6_2.
Meeusen, C. (2014). The parent-child similarity in cross-group friendship and anti-immigrant prejudice: A study among 15-year old adolescents and both their parents in Belgium. Journal of Research in Personality, 50, 46-55. https://doi.org/ 10.1016/j.jrp.2014.03.001

Myers, D. G. (2013). Social psychology (11th ed.). New York: McGraw Hill Higher Education.

Neuliep, J., Chaudoir, M., \& McCroskey, J. (2001). A cross-cultural comparison of ethnocentrism among Japanese and United States college students. Communication Research Reports, 18(2), 137-146.

Neuliep, J.W., Hintz, S.M., \& McCroskey, J.C. (2005). The Influence of ethnocentrism in organizational contexts: Perceptions of interviewee and managerial attractiveness, credibility, and effectiveness. Communication Quarterly, 53(1), 41-56.

Neuliep, J., \& McCroskey, J. (1997). The development of a U.S. and generalized ethnocentrism scale. Communication Research Reports, 14(4), 385-398.

Njoroge, M. W., \& Kirori, G. N. (2014). Ethnocentrism: Significance and effects on Kenyan society. African Journal of Political Science and International Relations, 8(9), 356-367.

Pettigrew, T. F., \& Tropp, L. R. (2011). When groups meet: The dynamics of intergroup contact. New York: Psychology Press.

Pettigrew, T. F. (1958). Personality and socio-cultural factors in intergroup attitudes: A cross-national comparison. Journal of Conflict Resolution, 2(1), 29-42.

Pettigrew, T. F. \& Meertens, R. W. (1995), Subtle and blatant prejudice in western Europe. European Journal of Social Psychology, 25, 57-75. https:// doi.org/10.1002/ejsp.2420250106

Pocovnicu, A., \& Vasilache, S. (2012). An interview based assessment of the influence of ethnocentrism in business. Revista De Management Comparat International, 13(3), 478-492.

Rubin, M., \& Badea, C. (2010). The central tendency of a social group can affect ratings of its intragroup variability in the absence of social identity concerns. Journal of Experimental Social Psychology, 46(2), 410-415. https://doi.org/10.1016/j.j esp.2010.01.001

Reichard, R. J., Dollwet, M., \& Louw-Potgieter, J. (2014). Development of cross-cultural psychological capital and its relationship with cultural intelligence and ethnocentrism. Journal of Leader- 
ship \& Organizational Studies, 21(2), 150-164. https://doi.org/10.1177/ 1548051813515517

Shaffer, M., Harrison, D., Gregersen, H., StewartBlack, J., \& Ferzandi, L. (2006). You can take it with you: Individual differences and expatriate effectiveness. Journal of Applied Psychology, 91(1), 109-125.

Sinclair, S., Dunn, E., \& Lowery, B. S. (2004). The relationship between parental racial attitudes and children's implicit prejudice. Journal of Experimental Social Psychology, 41(3), 283-289.

Stangor, C. (2016). The study of stereotyping, prejudice and discrimination within social psychology: A quick history of theory and research. In T. D. Nelson (Ed.), Handbook of prejudice, stereotyping, and discrimination (pp. 1-22). New York: Psychology Press Taylor \& Francis Group.

Sumner, W. G. (1906). Folkways. Boston, MA: Gin and Company.

Turner, H., \& Tajfel, J. (1986). The social identity theory of intergroup behavior. Psychology of Intergroup Relations, 5, 7-24.
Ulaan, K., Herani, I., \& Rahmawati, I. (2016). Prasangka mahasiswa Papua pada etnis Jawa di Kota Malang. Mediapsi, 2(1), 11-18.

Urbina, S. (2014). Essentials of Psychological Testing (2nd ed.). New Jersey: John Wiley \& Sons, Inc.

Van Veelen, R., Otten, S., Cadinu, M., \& Hansen, N. (2016). An integrative model of social identification: Self-stereotyping and self-anchoring as two cognitive pathways. Personality and Social Psychology Review, 20(1), 3-26. https://doi.org/ $10.1177 / 1088868315576642$

Vonofakou, C., Hewstone, M., \& Voci, A. (2007). Contact with out-group friends as a predictor of meta-attitudinal strength and accessibility of attitudes toward gay men. Journal of Personality and Social Psychology, 92(5), 804-820. https://doi. org/10.1037/0022-3514.92.5.804

Yulvika, U.E., Rivaie, W., \& Rustiyarso (2014). Analisis etnosentrisme antar-kelompok siswa di kelas XI IPS SMAN I Sungai Ambawang (unpublished paper). Pontianak: Program Studi Pendidikan Sosiologi FKIP UNTAN. 